\title{
Fulminant liver failure and transplantation after use of dietary supplements
}

\section{Clinical record}

A 26-year-old Indigenous man presented with icteric sclera and skin on a background of 6 weeks of fatigue. He worked as a dockyard labourer, had no previous medical history, was not taking any medications regularly, did not smoke cigarettes or use any illicit substances, and did not drink alcohol to excess. Results of a physical examination were otherwise unremarkable - he had no features to suggest chronic liver impairment.

Blood tests conducted on admission showed a hepatocellular pattern of liver injury with mild derangement in synthetic function. Results of all other investigations were unremarkable (Box 1). Although not disclosed initially by the patient, repeat questioning revealed that, 10 weeks before presentation, he had used two dietary supplements for a 1-week period. These were a whey protein powder and a weight loss supplement containing $70 \%$ Garcinia cambogia. He had discontinued use of both products after consistently developing rigors shortly after ingesting them.

After admission, the patient's liver synthetic function deteriorated (international normalised ratio rose to 2.5 and serum albumin level fell to $23 \mathrm{~g} / \mathrm{L}$ ). He also developed asterixis, without cognitive features of encephalopathy. Consequently, a liver biopsy was performed, with results of histopathology tests revealing submassive hepatic necrosis but no disease-specific features (Box 1). Liver transplantation was performed 2 months after presentation (results of histopathology tests are shown in Box 1). The patient's transplanted liver appears to be functioning well and the patient is making a slow recovery.

In the absence of any alternative cause of hepatotoxicity, an adverse event notification was made to the Therapeutic Goods Administration, detailing the use of the two dietary supplements. The public health division of the relevant state health department was also informed, and the two supplements were tested for heavy metals (arsenic, cadmium, chromium, copper, mercury, nickel, lead and zinc) and pharmaceuticals; however, no unexpectedly high levels of these substances were detected.
Rosemary J Smith MBBS, MRCPUK

Christina Bertilone MBBS, FRACGP, MPH

Andrew G Robertson FAFPHM, FRACMA, MPH

1 Geraldton Hospita Geraldton, WA

2 Department of Health, Perth, WA.

rosemary.smith2@ health.wa.gov.au

doi: 10.5694/mja15.00816
O ver 900 drugs and herbs have been reported to cause hepatotoxicity. ${ }^{1}$ In the United States, the use of herbal and dietary supplements is the second most common cause of idiosyncratic druginduced liver injury (DILI), after antimicrobial therapy. ${ }^{1}$ Of the herbal and dietary supplements, weight loss and body building supplements are most commonly implicated. ${ }^{2}$ In addition, contamination and adulteration of herbal supplements is common, ${ }^{3}$ with reported contaminants including undeclared antimicrobials, pharmaceuticals and heavy metals. ${ }^{2}$ Diagnosis of DILI is complicated by the tendency for herbal supplements to contain multiple ingredients, ${ }^{2}$ many of which are poorly characterised and could act synergistically. The protein supplement ingested by the patient in this case contained many ingredients, including green tea (Camellia sinensis) extract, green coffee extract, African mango extract, guarana, whey protein, and various vitamins and minerals. This, combined with his ingestion of a second supplement containing G. cambogia (active ingredient hydroxycitric acid), prohibits definitive identification of the causative agent or agents.

Historically, DILI has been overdiagnosed, with up to $48.5 \%$ of suspected cases of herb-induced hepatotoxicity being eventually attributed to other causes. ${ }^{4}$ To reduce the risk of misdiagnosis, causality assessments are routinely used. Many tools are available, but the Council for International Organizations of Medical Sciences (CIOMS) scale is most commonly used. ${ }^{4}$ This scale is liver specific and attributes a score based on seven items (Box 2), translating to causality grades of excluded, unlikely, possible, probable and highly probable for
DILI. Using this scale, DILI secondary to the protein supplement in combination with the G. cambogia supplement is probable for the patient in this case (total score, 6).

Of the supplements ingested by the patient in this case, the main ingredients previously associated with hepatotoxicity are green tea extract and G. cambogia. Green tea and green tea extract have been demonstrated to have beneficial effects on total cholesterol levels, low density lipoprotein cholesterol levels, blood pressure, ${ }^{5}$ and fasting blood glucose levels. ${ }^{6}$ However, over 60 case reports linking green tea extract with hepatotoxicity have been published. ${ }^{3}$ In many of these cases, the ascertainment of causality was complicated by the ingestion of more than one potential hepatotoxin. ${ }^{3}$ Green tea differs from black tea in that it is unfermented, preserving the catechins that are the probable toxic agent. Green tea is present in many dietary supplements and protein powders available in supermarkets, health food shops and pharmacies. The usual clinical picture is a hepatocellular pattern of liver injury occurring within 3 months of ingestion (range, 10 days to 7 months). ${ }^{7}$ Although most patients recover rapidly on cessation, fatal instances of acute liver failure have been described. Results of liver histopathology tests typically resemble acute hepatitis, with necrosis, inflammation and eosinophils present. Autoimmune features are usually absent. $^{7}$ This patient's clinical picture, biochemistry results and histopathology results are consistent with a green tea extract-induced liver injury.

Products containing G. cambogia are widely available and advertised as weight loss supplements, although the 
1 Results of tests conducted on admission and histopathology tests of liver biopsy specimen and explanted liver for a patient who developed fulminant liver failure after using dietary supplements

\section{Test}

Result (reference interval)

Serum alanine

aminotransferase

Serum aspartate

transaminase

Serum alkaline

phosphatase

Serum

gamma-glutamyl

transferase

Serum bilirubin

Serum albumin

International

normalised ratio

Anti-HAV IgM

HBs antigen,

anti-HBc IgM,

HBV-DNA

Anti-HCV antibody,

HCV-RNA

Imaging (dual-phase

computed tomography)

Anti-EBV IgM,

anti-EBV IgG

Anti-HEV IgM,

anti-HEV IgG

Anti-HSV IgM,

anti-HSV IgG

Anti-VZV IgM

anti-VZV IgG

Anti-CMV IgM,

anti-CMV IgG

Anti-nuclear

antibody

Anti-smooth

muscle antibody

Serum caeruloplasmin

Serum copper

Histopathology

tests - liver

biopsy specimen

Histopathology

tests -

explanted liver

$1520 \mathrm{U} / \mathrm{L}(<40 \mathrm{U} / \mathrm{L})$
$1430 \mathrm{U} / \mathrm{L}(<45 \mathrm{U} / \mathrm{L})$
$156 \mathrm{U} / \mathrm{L}(35-135 \mathrm{U} / \mathrm{L})$
$260 \mathrm{U} / \mathrm{L}(<60 \mathrm{U} / \mathrm{L})$
$174 \mu \mathrm{mol} / \mathrm{L}(<20 \mu \mathrm{mol} / \mathrm{L})$
$36 \mathrm{~g} / \mathrm{L}(35-50 \mathrm{~g} / \mathrm{L})$
$1.3(0.9-1.3)$
Not detected
Not detected

Not detected

No portal vein thrombosis

IgM negative, IgG positive

Not tested

IgM negative, type 1 IgG positive, type 2 IgG negative

IgM negative, IgG positive

lgM negative, IgG positive

$4 \mathrm{IU} / \mathrm{mL}(<7 \mathrm{IU} / \mathrm{mL})$

$\mathrm{O} \mathrm{IU} / \mathrm{mL}(\mathrm{O} \mathrm{IU} / \mathrm{mL})$

$0.23 \mathrm{~g} / \mathrm{L}(0.17-0.45 \mathrm{~g} / \mathrm{L})$

$12 \mu \mathrm{mol} / \mathrm{L}(11-23 \mu \mathrm{mol} / \mathrm{L})$

Multiple fragmented cores of hepatic parenchyma with panlobular and multilobular necrosis, consistent with submassive hepatic necrosis; no evidence of autoimmune hepatitis or significant copper or iron deposition

Loss of viable hepatocytes, collapse of liver parenchyma, reactive biliary hyperplasia, no cirrhosis or steatosis; between the necrotic areas were islands of regenerative nodules containing viable hepatocytes with disorganised architecture and without well formed portal tracts

$\mathrm{HAV}=$ hepatitis $\mathrm{A}$ virus. $\mathrm{HBs}=$ hepatitis B surface antigen.

$\mathrm{HBC}=$ hepatitis $\mathrm{B}$ virus core antibody. $\mathrm{HBV}=$ hepatitis $\mathrm{B}$ virus.

$\mathrm{HCV}=$ hepatitis $\mathrm{C}$ virus. $\mathrm{EBV}=$ Epstein-Barr virus. $\mathrm{HEV}=$ hepatitis $E$ virus. $\mathrm{HSV}=$ herpes simplex virus. $\mathrm{VZV}=$ varicella-zoster virus.

$\mathrm{CMV}=$ cytomegalovirus.
2 Summary of the Council for International Organizations of Medical Sciences scale ${ }^{4}$ for the hepatocellular pattern of liver injury in cases of suspected drug- and herb-induced liver injury, and scores for a patient who developed fulminant liver failure after using dietary supplements

\begin{tabular}{|c|c|c|}
\hline $\begin{array}{l}\text { Items scored for hepatocellular } \\
\text { injury }\end{array}$ & $\begin{array}{l}\text { Potential } \\
\text { score }\end{array}$ & $\begin{array}{l}\text { Patient's } \\
\text { score }\end{array}$ \\
\hline $\begin{array}{l}\text { 1. Time to onset from beginning/ } \\
\text { cessation of drug/herb ingestion }\end{array}$ & 1 to 2 & 1 \\
\hline $\begin{array}{l}\text { 2. Course of serum alanine } \\
\text { aminotransferase levels after } \\
\text { cessation of drug/herb } \\
\text { ingestion }\end{array}$ & -2 to 3 & 3 \\
\hline $\begin{array}{l}\text { 3. Risk factors (age and } \\
\text { alcohol use) }\end{array}$ & 0 to 2 & 0 \\
\hline $\begin{array}{l}\text { 4. Concomitant ingestion of } \\
\text { drug(s) or herbs(s) }\end{array}$ & -3 to 0 & 0 \\
\hline $\begin{array}{l}\text { 5. Search for non-drug/herb } \\
\text { causes* }\end{array}$ & -3 to 2 & 1 \\
\hline $\begin{array}{l}\text { 6. Previous information on } \\
\text { hepatotoxicity of the } \\
\text { drug/herb }\end{array}$ & 0 to 2 & 1 \\
\hline $\begin{array}{l}\text { 7. Response to unintentional } \\
\text { re-administration }\end{array}$ & -2 to 3 & 0 \\
\hline Total score $^{\dagger}$ & & 6 \\
\hline \multicolumn{3}{|c|}{$\begin{array}{l}\text { *Item } 5 \text { is scored according to the exclusion of } 12 \text { non-drug/herb } \\
\text { causes of hepatotoxicity, of which } 11 \text { were excluded for the patient } \\
\text { described in this article because serological exclusion of hepatitis } E \\
\text { virus was not performed (it was clinically unlikely and is not seen } \\
\text { locally in the absence of travel to an endemic area); as such, the } \\
\text { patient scored } 1 \text { for this item. }+ \text { Causality grades for total scores: } \leq 0 \text {, } \\
\text { excluded; } 1-2 \text {, unlikely; } 3-5 \text {, possible; } 6-8 \text {, probable; } \geq 9 \text {, highly } \\
\text { probable. }\end{array}$} \\
\hline
\end{tabular}

evidence supporting this effect is conflicting. In comparison with green tea extract, the evidence for G. cambogia as a hepatotoxin is less robust and the safety profile of G. cambogia has not been extensively studied. The substance has been associated with hepatocellular pattern DILI in several case reports, 8,9 but other potentially hepatotoxic pharmaceuticals or herbal supplements had also been ingested in these cases.

In 2009, the US Food and Drug Administration (FDA) recalled several Hydroxycut slimming supplements (Iovate Health Sciences International) following 23 case reports associating liver injury with ingestion of these products, including several cases in which the patient required liver transplantation or died. ${ }^{10}$ The implicated products varied in formulation, with some containing G. cambogia and all containing green tea extract. Following an investigation by the FDA Health Hazard Evaluation Board, it was concluded that Hydroxycut could cause idiosyncratic hepatotoxicity, although the exact causative agent was not identified. A subsequent case series examined the product constituents and concluded that green tea extract was the most likely causative agent, although this could not be 
Lessons from practice

- Health professionals should specifically question patients on their use of dietary supplements. Patients often do not mention use of such products owing to perceptions of product safety.

- Ascertaining causality is challenging. Scoring systems are available to help diagnose drug-induced liver injury and systematically exclude alternative causes.

- Increased regulation of herbal and dietary supplements, including better surveillance of adverse events associated with these products, could improve knowledge of their safety profiles.

definitively proven. ${ }^{10}$ There are similarities between the Hydroxycut scenario and the case described here, but, to our knowledge, no other cases of hepatotoxicity associated with whey protein powder and a weight loss supplement containing G. cambogia have been reported.

Competing interests: No relevant disclosures.

(c) 2016 AMPCo Pty Ltd. Produced with Elsevier B.V. All rights reserved.

References are available online at www.mja.com.au. 
1 Chalasani N, Fontana RJ, Bonkovsky HL, et al. Causes, clinical features, and outcomes from a prospective study of drug induced liver injury in the United States. Gastroenterology 2008; 135: 1924-1934.

2 Navarro VJ, Lucena MI. Hepatotoxicity induced by herbal and dietary supplements. Semin Liver Dis 2014; 34: 172-193.

3 Stickel F, Shouval D. Hepatotoxicity of herbal and dietary supplements: an update. Arch Toxicol 2015; 1-15.

4 Teschke R, Wolff A, Frenzel C, et al. Drug and herb induced liver injury: Council for International Organizations of Medical Sciences scale for causality assessment. World J Hepatol 2014; 6: 17-32.

5 Hartley L, Flowers N, Holmes J, et al. Green and black tea for the primary prevention of cardiovascular disease. Cochrane Database Syst Rev 2013; 6: CD009934.
6 Zheng $X, X \cup Y$, Li S, et al. Effects of green tea catechins with or without caffeine on glycemic control in adults: a meta-analysis of randomized controlled trials. Am J Clin Nutr 2013; 97: 750-762.

7 LiverTox: Clinical and research information on drug-induced liver injury. Green tea (Camellia sinensis). Bethesda: United States National Library of Medicine, 2015. http://livertox. nlm.nih.gov/GreenTea.htm (accessed Mar 2015).

8 Actis GC, Bugianesi E, Ottobrelli A, et al. Fatal liver failure following food supplements during chronic treatment with montelukast. Dig Liver Dis 2007; 39: 953-955.

9 Lee JK, Shin HP, Jeon JW, et al. A case of toxic hepatitis by weight-loss herbal supplement containing Garcinia cambogia. Soonchunhyang Med Sci 2014; 20: 96-98.

10 Fong TL, Klontz KC, Canas-Coto A, et al. Hepatotoxicity due to hydroxycut: a case series. Am J Gastroenterol 2010; 105: 1561-1566. 